ISSN 1676-3742

\title{
A presença de Maria na nova evangelização
}

\author{
The presence of Mary in the \\ new evangelization
}

Pedro K. Iwashita CSSp

\section{Resumo}

Este artigo é uma pesquisa sobre a Nova Evangelização como foi concebida por Bento XVI e seus predecessores, e como está sendo refletida e realizada pelo Papa Francisco. A Nova Evangelização é compreendida no sentido geral, que a Igreja deve cumprir animada pelo Espírito Santo, portanto realizada com um novo ardor, o que implica na necessidade de buscar novos métodos e formas para comunicar ao homem do mundo contemporâneo a verdade sobre Jesus Cristo, o que somente pode ser feito, vivenciando uma fé sólida e robusta, para que se possa ir de encontro das necessidades das pessoas e do mundo de hoje. Não se trata principalmente de anunciar uma doutrina, mas de propor um encontro pessoal com Jesus Cristo. Maria é o exemplo de discípula de Jesus Cristo e de evangelizadora, e por isso ela é paradigma de uma Nova Evangelização.

Palavras-chave: Nova Evangelização, Jesus Cristo, Igreja, Maria.

\begin{abstract}
This article is a research on the New Evangelization as it was conceived by Benedict XVI and his predecessors, and it is being reflected and made by Pope Francis. The New Evangelization is understood in the general sense,
\end{abstract}


that the Church must comply animated by the Holy Spirit therefore performed with a new zeal, which implies the need to seek new methods and ways to communicate to man in the contemporary world the truth about Jesus Christ, which can only be done, experiencing a solid and strong faith, so that we can meet the needs of people and the world today. It is not principally to announce a doctrine, but to propose a personal encounter with Jesus Christ. Mary is an example of a disciple of Jesus Christ and evangelizing, and so it is a paradigm of a New Evangelization.

Keywords: New Evangelization, Jesus Christ, Church, Mary.

\section{Introdução}

É somente numa perspectiva de fé que podemos compreender a evangelização, que sempre tem como meta transmitir a fé cristã, ${ }^{1}$ propor a riqueza que essa fé nos oferece e nos proporciona. Mas qual é a expectativa do homem de hoje? Sente ele necessidade de ser evangelizado? O que explica o esvaziamento das igrejas em muitos países tradicionalmente cristãos? O que explica o abandono em massa do cristianismo? O que explica a indiferença religiosa de muitos? Quando se fala em Nova Evangelização, é preciso se questionar se somos evangelizados até as profundezas de nosso ser. Carl Gustav Jung, que analisou a psique humana, chegou à constatação de que muitos cristãos permaneciam pagãos na sua estrutura psíquica mais profunda, e isso significa que uma Nova Evangelização deve ter em vista a pessoa humana no seu todo, com a sua estrutura psíquica consciente e inconsciente. A mensagem cristã deve chegar até o profundo 2 , até o inconsciente, onde habitam os "deuses", e que também devem ser evangelizados, "porque a alma humana não é apenas naturaliter christiana, mas também pagana" . Com o abandono em massa de cristãos, ressurgem os deuses pagãos, o que em termos de desenvolvimento psíquico humano representa um retrocesso ou uma regressão. Daí a importância fundamental para a humanidade de uma Nova Evangelização. A pessoa

\footnotetext{
${ }^{1}$ Cf. SÍNODO DOS BISPOS. A nova evangelização para a transmissão da fé cristã. Instrumentum laboris. Brasília: CNBB, 2012.

${ }^{2}$ Sobre um programa de evangelização das profundezas, cfr. PACOT, Simone. Lévangélisation des profondeurs. 3 volumes. Paris: Cerf, 2002-2003. Trad. Bras.: PACOT, Simone. A evangelização das profundezas. Nas dimensões psicológica e espiritual. Vol 1. Aparecida: Santuário, 2001.

${ }^{3}$ GOLDBRUNNER, J., Realização. Antropologia na pastoral e na educação. São Paulo: Herder, 1968.
} 
é atingida no seu cerne profundo, se a evangelização é veiculada através dos elementos da própria cultura ${ }^{4}$, o que se chama inculturação.

A transmissão da fé cristã diz respeito em primeiro lugar à comunidade dos discípulos de Jesus Cristo, vivendo nas respectivas Igrejas particulares, reunindo-se regularmente nas celebrações litúrgicas, para celebrar os sacramentos, principalmente a Eucaristia e transmitindo a fé aos filhos. A Nova Evangelização é compreendida no sentido geral, que a Igreja deve cumprir animada pelo Espírito Santo, portanto realizada com um novo ardor, o que implica na necessidade de buscar novos métodos e formas para comunicar ao homem do mundo contemporâneo a verdade sobre Jesus Cristo, o que somente pode ser feito, vivenciando uma fé sólida e robusta, para que se possa ir de encontro das necessidades das pessoas e do mundo de hoje. ${ }^{5}$

A pergunta é como apresentar a fé cristã ao homem de hoje, como suscitar uma reflexão sobre o amor de Cristo, morto e ressuscitado, como conciliar fé e razão a fim de que o ato de fé seja livre e forte, são algumas das questões que surgem quando se pensa em Nova Evangelização. ${ }^{6} \mathrm{O}$ ponto decisivo é colocar o homem de hoje diante da urgência da fé em Jesus Cristo. ${ }^{7}$ Em face desta urgência, a criação pelo Papa Bento XVI do Conselho Pontifício ${ }^{8}$ para a promoção da Nova Evangelização, foi extraordinária e atraiu a atenção do mundo, e essa expectativa é uma demonstração e uma prova do caráter profético da intuição de Bento XVI. Não se trata de deixarmos de nos debruçar sobre o hic et nunc, mas temos a obrigação de considerarmos a época em que vivemos, a fim de que cada um possa tomar consciência da própria responsabilidade, voltando ao mesmo tempo para o futuro com lucidez iluminados por uma fé vigilante e atenta. ${ }^{9}$

\footnotetext{
${ }^{4}$ Trabalho importante tem sido feito no sentido de uma metodologia de evangelização, de uma conversão até as profundezas, por Carlos Rafael Cabarrús SJ, doutor em antropologia cultural. Cfr. Cabarrús, C. R. Crescer bebendo do próprio poço. Oficina de crescimento pessoal. São Paulo: Loyola, 1999.

${ }^{5}$ Cfr. SÍNODO DOS BISPOS, op. cit. pp. 10-11.

${ }^{6}$ Cf. FISICHELLA, R., La nouvelle évangélisation. Paris: Salvator, 2012, p. 8.

${ }^{7}$ Ibidem, p. 9.

${ }^{8}$ Carta Apostólica em forma de "Motu próprio": Ubicumque et semper do Sumo Pontífice Bento XVI com a qual se institui o Pontifício Conselho para a promoção da Nova Evangelização, dado em Castel Gandolfo, no dia 21 de Setembro de 2010, Festa de São Mateus, Apóstolo e Evangelista, no sexto ano de Pontificado do Papa Bento XVI.

${ }^{9}$ Cf. FISICHELLA, R., op. cit. p. 10.
} 
Fundamental é a perspectiva apresentada pela Instrumentum laboris, que "a fé cristã não é somente uma doutrina, uma sabedoria, um conjunto de regras morais, uma tradição. A fé cristã é um encontro real, uma relação com Jesus Cristo. Transmitir a fé significa criar em cada lugar e em cada tempo as condições para que este encontro entre os homens e Jesus aconteça"10. Com esse olhar de fé em relação à pessoa de seu Filho, que Maria tem a nos ensinar na Nova Evangelização, pois ela continua dizendo: "Fazei tudo o que ele vos disser" (Jo 2,5).

Este estudo seguirá, portanto, o percurso, partindo da necessidade urgente de anunciar o Evangelho, responder ao mandato de Jesus, que disse "Ide, pois, ensinais todas as nações", e da constatar que a Igreja em todas as épocas procurou responder a esse chamado, uma vez que a missão faz parte essencial da natureza da Igreja. Essa missão assumiu formas novas no decorrer da história, e hoje deve atender às novas exigências do mundo donde nasce o projeto de uma Nova Evangelização.

O conceito de Nova Evangelização foi introduzido por João Paulo II, para significar a evangelização das regiões de antiga cristianização. Bento XVI, na pegada dos predecessores, concebe a Nova Evangelização também como resposta para a Igreja inteira através de um novo impulso missionário, através de uma nova e generosa abertura ao dom da graça, e partilha desse dom inestimável, que Deus nos concede comunicando-nos a sua própria Vida, o que pressupõe uma vida de fé. E para essa vida de fé que a Virgem Maria é modelo e protótipo, pois ela é a primeira que acreditou no seu Filho e se tornou assim primeira discípula missionária. Como mulher de fé, Maria está presente hoje na Nova Evangelização.

\section{Necessidade da Nova Evangelização}

Conforme Bento XVI, "a Igreja tem o dever de anunciar sempre e em toda a parte o Evangelho de Jesus Cristo. Ele, o primeiro e supremo Evangelizador, no dia da sua ascensão ao Pai, ordenou aos Apóstolos: «Ide, pois, ensinai todas as nações, batizando-os em nome do Pai, do Filho e do Espírito Santo, ensinando-as a cumprir tudo o que vos tenho mandado» (Mt 28,19-20). Fiel a este mandamento da Igreja, povo que Deus adquiriu para si a fim de que proclame as suas obras admiráveis (cf. $1 P d 2,9$ ), desde o dia de Pentecostes no qual recebeu em dom o Espírito Santo (cf. At 2,14), nunca se cansou de dar

${ }^{10}$ SÍNODO DOS BISPOS. A nova evangelização para a transmissão da fé cristã. Instrumentum laboris. Brasília: CNBB, 2012, nº 18 . 
a conhecer ao mundo inteiro a beleza do Evangelho, anunciando Jesus Cristo, verdadeiro Deus e verdadeiro homem, o mesmo «ontem, hoje e sempre» $(H b 13,8)$, que com a sua morte e ressurreição realizou a salvação, levando a cumprimento a promessa antiga. Portanto, a missão evangelizadora, continuação da obra querida pelo Senhor Jesus, é necessária e insubstituível para a Igreja, expressão da sua própria natureza" ${ }^{11}$.

Esta missão da Igreja sempre assumiu formas novas no decorrer da história, e agora ela está confrontada com o fenômeno do afastamento da fé em sociedades e culturas, anteriormente impregnadas pelo Evangelho. As sociedades passam por transformações complexas, abalando seus fundamentos e modificando a própria percepção do mundo. O progresso da ciência e da técnica, a ampliação das possibilidades de vida e da liberdade individual, as mudanças no campo econômico, a miscigenação, o caldeirão cultural, provocado pelo movimento migratório, e a consequente interdependência entre os povos da terra, todos esses fatores trouxeram consequências para a vivência religiosa do homem contemporâneo. Por um lado isso foi positivo, mas por outro ocorreu uma preocupante perda do sagrado, e o questionamento de verdades religiosas, que pareciam inquestionáveis, como a fé num Deus Criador e providente, e em Jesus Cristo como único Salvador, trazendo como consequência o vazio interior, pois o homem ao pretender se colocar no lugar do Criador, vai se ver desprovido daquilo que constitui o fundamento de tudo. ${ }^{12}$

O Concílio Vaticano II já tinha tomado consciência dessas mudanças no mundo, e estabeleceu entre os temas principais a questão da relação entre a Igreja e o mundo contemporâneo. E por isso, os Papas Paulo VI e João Paulo II, continuando dentro do espírito do Concílio Vaticano II, ponderaram sobre a necessidade de encontrar formas adequadas para permitir que as pessoas do mundo de hoje continuassem a ouvir a Palavra viva e eterna do Senhor.

Paulo VI já dizia: "se demonstra cada dia mais necessário, e isto por causa das situações de descristianização frequentes nos nossos dias, igualmente para multidões de homens que receberam o batismo, mas vivem fora de toda a vida cristã, para as pessoas simples que, embora tenham uma certa fé, conhecem mal os fundamentos dessa mesma fé, para intelectuais que sentem a falta de um conhecimento de Jesus Cristo sob uma luz diversa da dos ensinamentos recebidos na sua infância, e para muitos outros ainda"13.

\footnotetext{
${ }^{11}$ BENTO XVI. Carta Apostólica: Ubicumque et semper.

${ }^{12}$ Ibidem.

${ }^{13}$ Evangelii Nuntiandi (EN), 52, apud BENTO XVI. Carta Apostólica: Ubicumque et semper.
} 
João Paulo II introduziu o conceito de "nova evangelização", significando a tarefa que a Igreja deve assumir, principalmente nas regiões de antiga cristianização. Na Exortação Apostólica Christifideles laici ele dizia: "Países inteiros e nações, onde a religião e a vida cristã foram em tempos tão prósperas e capazes de dar origem a comunidades de fé viva e operosa, encontram-se hoje sujeitos a dura prova, e, por vezes, até são radicalmente transformados pela contínua difusão do indiferentismo, do secularismo e do ateísmo. É o caso, em especial, dos países e das nações do chamado Primeiro Mundo, onde o bem-estar econômico e o consumismo, embora à mistura com tremendas situações de pobreza e de miséria, inspiram e permitem viver "como se Deus não existisse". Ora, a indiferença religiosa e a total insignificância prática de Deus nos problemas, mesmo graves, da vida não são menos preocupantes e subversivos do que o ateísmo declarado. E também a fé cristã, mesmo sobrevivendo em algumas manifestações tradicionais e ritualistas, tende a desaparecer nos momento mais significativos da existência, como são os momentos do nascer, do sofrer e do morrer (...) Noutras regiões ou nações, porém, conservam-se bem vivas ainda tradições de piedade e de religiosidade popular cristã; mas, esse patrimônio moral e espiritual corre hoje o risco de esbater-se sob o impacto de múltiplos processos, entre os quais sobressaem a secularização e a difusão das seitas. Só uma nova evangelização poderá garantir o crescimento de uma fé límpida e profunda, capaz de converter tais tradições numa força de liberdade autêntica. É urgente, sem dúvida, refazer em toda a parte o tecido cristão da sociedade humana. Mas, a condição é a de se refazer o tecido cristão das próprias comunidades eclesiais que vivem nesses países e nessas nações" ${ }^{14}$.

Bento XVI, assumindo a preocupação dos Predecessores, quis oferecer respostas adequadas a fim de que a Igreja inteira, deixando-se regenerar pela força do Espírito Santo, possa se apresentar ao mundo contemporâneo com um impulso missionário capaz de promover uma nova evangelização. Existem as Igrejas de antiga fundação, que embora vivendo realidades bastante diferenciadas, esperam diferentes impulsos de evangelização: com efeito, em alguns territórios, apesar do progresso do fenômeno da secularização, "a prática cristã ainda manifesta uma boa vitalidade e um profundo arraigamento na alma de populações inteiras; noutras regiões, ao contrário, observa-se um distanciamento mais claro da fé por parte da sociedade no seu conjunto, com um tecido

${ }^{14}$ JOÃO PAULO II, Christifideles laici, 34, apud BENTO XVI. Carta Apostólica: Ubicumque et semper. 
eclesial mais frágil, embora não desprovido de elementos de vivacidade, que o Espírito Santo não deixa de suscitar; além disso, nós infelizmente conhecemos regiões que parecem quase completamente descristianizadas, em que a luz da fé é confiada ao testemunho de pequenas comunidades: estas terras, que teriam necessidade de um renovado primeiro anúncio do Evangelho, parecem ser particularmente refratárias a muitos aspectos da mensagem cristã"15.

Essa diversidade de situações exige um discernimento atento, e "nova evangelização" não quer dizer que se elabore uma única fórmula igual para todas as situações. O importante é que se viva um renovado impulso missionário, como expressão de uma nova e generosa abertura ao dom da graça, que não é simplesmente um desígnio humano de expansão, mas a partilha do dom inestimável, que Deus nos concede comunicando-nos a sua própria Vida. ${ }^{16}$

Trata-se de viver profundamente uma vida de fé, pois o testemunho dessa vida de fé pode suscitar a pergunta sobre qual é a razão de se ter esperança. "O anúncio do Evangelho é confrontado hoje, muitas vezes, com a indiferença de quem já não lhe dá importância e não tem interesse em ouvi-lo. Como despertar nos corações um renovado interesse pela mensagem da salvação? Aqui entra o papel do testemunho de quem crê. É muito importante que os cristãos mostrem a sua fé através de convicções firmes, da vida coerente com ela, da alegria e da serenidade que ela traz. Mostrem, por outro lado, que a fé muda a pessoa para melhor e a torna humanamente rica de virtudes"17.

E aqui vemos a importância do testemunho que deu a Virgem Maria sobre uma vida de fé. O Novo Testamento exalta justamente a fé de Maria, que com o seu exemplo de vida de fé, fé em Deus, fé em seu Filho se tornou paradigma de evangelizada e evangelizadora.

\section{Maria, protótipo daquele que crê: o testemunho do Novo Testamento}

$\mathrm{Na}$ chegada de Maria à casa de Isabel, ela foi saudada com alegria e Isabel inspirada pelo Espírito Santo proclamou: Feliz aquela que creu, pois o que lhe foi dito da parte do Senhor será cumprido! (Lc 1,45). Desta forma, no episódio da Visitação ficamos sabendo o que tinha acontecido no segredo de

\footnotetext{
${ }^{15}$ BENTO XVI. Carta Apostólica: Ubicumque et semper.

${ }^{16}$ Ibidem.

${ }^{17}$ SCHERER, Cardeal Odilo Pedro. Por ocasião do Domingo das Missões. Disponível em: http:// www.cnbb.org.br/articulistas/cardeal-odilo-pedro-scherer/13031-missao-nova-evangelizacao Acessado em 21/01/2014, às 11:40 hs.
} 
Nazaré e na privacidade de Maria, mas que agora num diálogo com uma interlocutora, que também acolhe o acontecimento na fé, pôde ser manifestado e assumir um caráter objetivo e público. ${ }^{18}$

Em Nazaré Maria acreditou na mensagem do anjo, que depois da saudação disse: "Não temas, Maria! Encontraste graça junto de Deus! Eis que conceberás no teu seio e darás à luz um filho, e tu o chamarás com o nome de Jesus. Ele será grande, será chamado Filho do Altíssimo, e o Senhor Deus lhe dará o trono de Davi, seu Pai; ele reinará na casa de Jacó para sempre, e o seu reinado não terá fim" (Lc 1,30-33).

Antes de dar a resposta, Maria procurou saber como isso iria acontecer, "se eu não conheço homem" (Lc 1,34), e à essa pergunta o anjo lhe respondeu: "O Espirito Santo virá sobre ti e o poder do Altíssimo vai te cobrir com a sua sombra; por isso o Santo que nascer será chamado Filho de Deus. Também Isabel, tua parenta, concebeu um filho na velhice, e este é o sexto mês para aquela que chamavam de estéril. Para Deus, com efeito, nada é impossivel (Lc 1,35-37). Dizendo: Eu sou a seva do Senhor; faça-se em mim segundo a tua palavra!" (Lc 1,38), Maria fez um ato de fé, o primeiro ato de fé no Verbo, o primeiro ato de fé cristão.

O texto bíblico diz que Maria ficou intrigada (Lc 1,29) ao ouvir a saudação do anjo. Ficar intrigado significa, ficar perplexo, curioso ou até mesmo desconfiado ${ }^{19}$ Ora essa pequena observação sobre a atitude ou comportamento de Maria, é rica em informações sobre o que se passou no interior de Maria,

Maria não está faltando com a fé. Ela não está duvidando no sentido da incredulidade ou do ceticismo. É mais num sentido do discernimento ${ }^{20}$, que conforme Marcozzi (2003), é a perscrutação e o juízo acerca daquilo que move nossas ações, e como os entes que podem incutir ou causar tais moventes são de natureza espiritual, usa-se o termo "dos espíritos" para identificar esse tipo de discernimento. ${ }^{21}$

Maria, na verdade, está agindo com prudência, e foi a mesma atitude diante do anúncio do anjo, perguntando: "como é que vai ser isso, se eu não conheço homem algum?" (Lc 2,34).

\footnotetext{
${ }^{18}$ Cfr. Cantalamessa, R., Maria, um espelho para a Igreja, p. 33.

${ }^{19}$ Cf. Holanda Ferreira, A. B. de. Mini Aurélio. O Dicionário da Língua Portuguesa. $6^{\mathrm{a}}$ ed. Curitiba: Positivo, 2004.

${ }^{20}$ Cf. Loiola, Santo Inácio. Exercícios espirituais. $1^{\text {a }}$ ed. Porto Alegre, 1966, p. 199-204.

${ }^{21}$ Cf. Marcozzi, V., "Discernimento dos espíritos". In: Borrielo, L. et alii (Dir.). Dicionário de Mística. São Paulo: Loyola/Paulus, 2003, p. 334.
} 
Com certeza Maria está primeiramente analisando tudo à luz da fé, fruto de uma longa escuta da palavra de Deus e das profecias messiânicas: "porei hostilidade entre ti e a mulher, entre tua linhagem e a linhagem dela. Ela te esmagará a cabeça e tu lhe ferirás o calcanhar" (Gn 3,15); o anúncio do nascimento de um filho: "pois sabei que o Senhor mesmo vos dará um sinal: Eis que a jovem concebeu e dará à luz um filho e por-lhe-á o nome de Emanuel" (Is 7,14); "porque um menino nos nasceu, um filho nos foi dado, ele recebeu o poder sobre seus ombros, e lhe foi dado este nome: Conselheiro-maravilhoso, Deus forte, Pai-eterno, Príncipe-da-paz, para que se multiplique o poder, assegurando o estabelecimento de uma paz sem fim sobre o trono de Davi e sobre o seu reino, firmando-o, consolidando-o sobre o direito e sobre a justiça” (Is 9,5-6).

Maria tem também na sua memória as mulheres do Antigo Testamento, Míriam, Ana, Rute, Judite, Ester entre outras, e algumas delas conseguiram gerar apesar da esterilidade, como Sara (Gn 16,1-2) ou Ana (1Sm 2,1-10), cujo hino sobre o qual parece que o Magnificat está calcado.

$\mathrm{O}$ anúncio a Maria acontece, portanto num contexto de muitas expectativas pela vinda do Salvador, pelo nascimento do Messias. Talvez fosse naquela época, sonho de qualquer mulher israelita, ser a mãe do Messias, e neste contexto de sugestionabilidade, Maria sendo uma jovem mulher muito sensata, quis talvez checar os seus sentidos ficando intrigada $(\operatorname{Lc} 1,29)$ diante da mensagem do anjo. Ela não está duvidando de Deus. Na verdade ela está duvidando de si mesma: será que não estou alucinando ${ }^{22}$ ou delirando ${ }^{23}$ ? É claro que, na realidade, Maria não está alucinando e nem delirando, pois o fato de ela estar checando os próprios sentidos, é uma prova de sua lucidez e pleno uso da razão. E isto é muito importante, porque está mostrando que a fé de Maria é uma fé dinâmica, uma fé que vem da palavra de Deus, uma fé que se nutre da oração na confiança e na entrega a Deus, uma fé que é feita de desafios que precisam ser superadas, porque a fé de Maria não é uma receita pronta, feita de facilidades. Em Lucas lemos que Maria ao encontrar o menino Jesus no templo conversando com os doutores, disse-lhe: "Meu filho, por que

\footnotetext{
${ }^{22}$ Alucinação é um termo da psiquiatria que designa um estado alterado de consciência, e que pode ser um fenômeno normal ou mórbido. Cf. Bertolote, J. M. (Org.). Glossário de termos de psiquiatria e saúde mental da CID-10 e seus derivados. Porto Alegre: Artes Médicas, 1997, p. 34. Alucinação é sensopercepção de algo ou de alguém na ausência do objeto ou da pessoa. Cf. Ibidem, p. 34.

${ }^{23}$ Ibidem, p. 60: delírio é uma "convicção ou juízo falso, incorrigível, fora dos padrões da realidade e incompatível com as crenças sociais da cultura e do meio do indivíduo".
} 
agiste assim conosco? Olha que teu pai e eu, aflitos te procurávamos. Ele respondeu: Por que me procuráveis? Não sabieis que devo estar na casa de meu Pai? Eles, porém, não compreenderam a palavra que ele lhes dissera" (Lc 2,48-50). Esse testemunho do Evangelho revela que Maria teve que crescer no caminho da fé, e que portanto a sua fé era dinâmica, e não uma fé estática, no sentido de que tudo teria sido claro de antemão para ela.

$\mathrm{Na}$ Anunciação, Maria demonstrou uma fé madura, responsável, e, com certeza, ela não está pensando somente em si mesma, mas também no seu povo, na humanidade que aguardava o Salvador. Depois de muito bem ponderar, Maria diz o seu sim pronunciando o fiat (Lc 1,38). Esse fiat (façase) de Maria foi pleno e sem impor condições. É um fiat que já havia ressoado em outros momentos cruciais da história: o fiat de Deus (Gn 1) no começo da criação, e o fiat de Jesus na redenção (Mt 26,39; Lc 23,46). ${ }^{24} \mathrm{O}$ primeiro, isto é, o fiat lux foi o "sim" divino na pessoa que o pronuncia; o segundo, o fiat de Jesus no Getsêmani, é o ato de um Deus; humano porque é pronunciado segundo a vontade humana, divino porque esta vontade pertence à pessoa do Verbo; o fiat de Maria é o "sim" humano de uma criatura humana. Nele, tudo recebe seu valor pela graça. Antes do "sim" decisivo de Cristo, tudo que há de consentimento humano à obra da redenção está expresso neste fiat de Maria". ${ }^{25}$ Conforme Karl Rahner: "Num instante que nunca mais vai desaparecer e que permanece válido por toda a eternidade, a palavra de Maria foi a palavra da humanidade, e o seu "sim" foi o Amém de toda a criação ao "sim" de Deus". ${ }^{26}$

Todavia ato de fé de Maria não foi nada fácil. Tornar-se a mãe de um filho rei, cujo reinado será eterno, significava ser a mãe do Messias, sonho de toda mulher judia, todavia ceder a tais sentimentos ou raciocinar desta forma é uma forma muito humana e carnal, porque uma fé genuína e pura, significa sempre, antes de ser um privilégio, é ter que morrer um pouco, e assim foi com Maria no seu ato de fé diante da proposta de Deus, que "jamais engana, nem arranca das criaturas seu consentimento de maneira sub-reptícia, escondendo-lhes as consequências que irão enfrentar"27 À luz do Espírito Santo, que acompanha o chamado de Deus, Maria deve ter previsto que o seu caminho não seria diferente dos que a precederam na fé, como profeta Jeremias ( $\mathrm{Jr}$ $1,19)$, e que na verdade vai se confirmar como sendo mais difícil ainda nas

\footnotetext{
${ }^{24}$ Cf. Cantalamessa, R., Maria, um espelho para a Igreja, p. 33-34.

${ }^{25}$ Cantalamessa, R. Op. cit., p. 34.

${ }^{26}$ Rahner, K., apud. Cantalamessa, R. Op. cit., 34.

${ }^{27}$ Cantalamessa, R., p. 35.
} 
palavras de Simeão: "Eis que este menino foi colocado para a queda e para o soerguimento de muitos em Israel, e como um sinal de contradição - e a ti uma espada transpassará tua alma - para que se revelem os pensamentos íntimos de muitos corações" (Lc 2,34-35).

$\mathrm{Na}$ verdade, Maria se encontrou sozinha diante do acontecido. Com quem ela teria podido falar para explicar o que tinha acontecido? E quem teria acreditado se dissesse que a criança concebida por ela seria obra do Espírito Santo? "Isto nunca aconteceu antes dela, nem irá acontecer depois. Maria conhecia certamente o que estava escrito no livro da lei: se, por ocasião das núpcias, fosse constatado que a moça já não era virgem, deveria ser levada à entrada da casa de seu pai para ser apedrejada pelos habitantes da cidade (Dt 22,20s)"28. Hoje se fala no risco da fé, e no caso de Maria tratou-se de um risco real.

Se acreditar significa avançar apesar de que as sinalizações da estrada estejam dizendo para voltar, então sem dúvida Maria foi a crente por excelência, e ninguém poderá se igualar a ela, que se encontrou completamente abandonada nos braços do Absoluto, acreditando antes de qualquer confirmação ou convalidação por parte dos eventos e da história, e por isso vale para ela a bem-aventurança proclamada por Jesus: "bem-aventurados os que sem terem visto, acreditam!" (Jo 20,29), e Maria foi a primeira daqueles que, sem terem visto, acreditaram. ${ }^{29}$

$\mathrm{Na}$ imensa esteira dos crentes que forma a Igreja, na ponta inicial dessa esteira se encontra Maria com o seu fiat. Se se trata do grande rio da oração que flui na Igreja, na nascente encontramos Jesus que reza, e quando se trata do grande rio da fé, encontramos a fé de Maria, antes mesmo da fé dos apóstolos. ${ }^{30}$ Fazendo assim, Maria nos mostrou a importância da fé, pois a graça não pode agir se faltar a fé. "A fé é a base de tudo; é a primeira e a "melhor" obra a ser cumprida. A obra de Deus é esta, diz Jesus: que acrediteis (Jo 6,29). A fé é tão importante porque é a única que conserva à graça a sua gratuidade. Não procura inverter as partes fazendo de Deus um devedor e do homem um credor. Por isso, a fé agrada tanto a Deus que ele, no seu relacionamento com o homem, faz praticamente tudo depender dela." ${ }^{\prime 1}$

A longa história de fé do Antigo Testamento, de tantas mulheres fiéis, como Sara, juntamente com os Patriarcas, encontrou o seu cumprimento na

\footnotetext{
${ }^{28}$ Ibidem, p. 35.

${ }^{29}$ Cf; Cantalamessa, R., p. 35-36.

${ }^{30}$ Ibidem, p. 36.

${ }^{31}$ Cantalamessa, R., p. 42.
} 
fé de Maria, que acolheu a Palavra de Deus, que se dirigiu a ela, e que se fez carne e nasceu como luz para os homens, de modo que em Maria, a fé se mostrou cheia de fruto, e esse caminho da fé do Antigo Testamento se realiza no seguimento de Maria a seu Filho Jesus, deixando-se transformar por Ele. Maria se envolveu toda na confissão de fé, de modo que no seu vínculo com Jesus, Maria está intimamente associada com aquilo em que acredita. ${ }^{32}$

Desta forma, Maria se configura como a representante digna da humanidade, a mãe dos viventes, a Nova Eva, no pensamento dos Padres da Igreja, que em contraposição à Eva, que duvidou, Maria é aquela que creu.

\section{As dimensões da fé de Maria}

Comparando a atitude de fé de Maria com a de Zacarias, constatamos de um lado, que Zacarias era um homem justo diante de Deus (Lc 1, 6), irrepreensível, seguindo todos os mandamentos e estatutos dos Senhor, porém, de outro lado, ele faltou com a fé diante da mensagem do anjo; é prudente demais em sua fé, racional e humano demais, pois pede um sinal para Deus (Lc 1, 18). Pedir um sinal a Deus, quando ele espera uma adesão de fé, é pedir um suporte humano, qualquer coisa que nos seja conatural. A razão humana pode, com efeito, estremecer diante do abismo divino que se estabelece em nossa alma pela adesão voluntária da fé. Não é necessariamente por má vontade de não querer crer, que se pede um sinal, mas é para ganhar tempo, o que denota falta de generosidade. A razão reclama também um sinal instintivamente, para melhor refletir, para verificar se tudo é realmente querido por Deus. ${ }^{33}$

Maria, ao contrário de Zacarias, sob a condução do Espírito Santo, adere com a espontaneidade de uma criança pequena muito amada do Pai. Ela adere imediatamente, sem pedir um sinal, e o anjo the dá um sinal por acréscimo, e em abundância, a saber, ela vai ficar grávida, vai dar à luz um filho (Lc 1, 30), e mais um sinal ainda, Isabel, sua prima, que concebe um filho na velhice, quando já era considerada estéril (Lc, 1,36). O verdadeiro motivo de sua adesão não é o sinal, mas está muito bem expresso em sua resposta ao anjo: "Eu sou a serva do Senhor; faça-se em mim segundo a tua palavra!" (Lc 1, 38). Maria crê na plenitude da palavra divina porque é a Palavra de Deus. Ela não tem a pretensão de reconduzir a amplitude e a profundidade dessa

\footnotetext{
${ }^{32}$ Cf. PAPA FRANCISCO. Lumen fidei, 58-59. São Paulo: Paulus/Loyola, 2013.

${ }^{33}$ Cf. Philippe, M.-D. Mystère de Marie. Croissance de la vie chrétienne, p. 96-97.
} 
palavra divina à compreensão humana que ela tem dela, e também não disse: "sim, aceito ser a mãe de Deus", mas sim, "faça-se em mim segundo a tua palavra". Ela recebe a palavra de Deus como a luz, como fonte e princípio de toda luz, de todo conhecimento. Sua inteligência é toda acolhida dessa luz, não querendo de forma alguma restringi-la, diminui-la. Eis a atitude filial de uma criança que recebe a palavra do Pai como um absoluto que não se discute, mas que se recebe como um tesouro. ${ }^{34}$

É claro, Maria perguntara ao anjo: "Como é que vai ser isso, se eu não conheço homem algum?" (Lc 1, 34). Contudo se se olha a intenção do coração de Maria, como nos convida a fazer Santo Agostinho, esse "como" de Maria não é um desejo de justificação para estar segura da palavra de Deus, e nem é também um retorno sobre ela mesma para ganhar tempo, mas é o "como" da criança que não está entendendo, e pergunta o que é preciso fazer para entrar plenamente naquilo que Deus espera dela. O “como" de Maria é fruto do amor obediente e do temor de Deus, que não quer errar e desfigurar a vontade de Deus. A pureza toda divina desse ato de fé da criança que adere à palavra de Deus, é a manifestação da primeira qualidade da fé cristã. Este primeiro ato de fé explicitamente cristão, como Maria a explicitou, se exerceu com uma pureza toda divina. ${ }^{35}$

Outra dimensão da fé de Maria é o seu realismo. Por seu ato de fé na anunciação, toda a sua inteligência adere à palavra viva de Deus, ao Verbo que se encarna nela, pelo fato mesmo, de que toda a vida humana de Maria se encontra aí engajada nesse ato de fé. O Verbo de Deus está presente nela, habita nela e se apodera de todas as forças de sua inteligência, de seu coração e de sua sensibilidade. Todo o seu ser está mobilizado para Deus e por Deus. É preciso compreender bem o caráter realista do ato de fé de Maria, que transforma toda a sua vida, e que num instante exige dela um consentimento profundo, sem restrição à vontade amorosa de Deus sobre ela. Santo Tomás de Aquino disse que a fé nos conduz à realidade divina, e que, portanto ela é conhecimento mais realista. A fé determina não somente nosso intelecto prático. O fiat de Maria na anunciação nos revela muito bem o realismo divino de seu ato de fé. Se, às vezes, a fé nos parece um conhecimento abstrato, é porque ocorre em nós de uma maneira humana demais, segundo nosso modo natural de conhecer, maneira de abstração de nosso conhecimento, que não

\footnotetext{
${ }^{34}$ Ibidem, p. 98-99.

${ }^{35}$ Ibidem, p. 99-100.
} 
é intuitiva e realista. Pela caridade e pelo dom da inteligência, o ato de fé se desabrocha em uma experiência amorosa da presença íntima de um Deus que é Pai, e que age sobre nós com amor, e que, portanto nos comunica algo de seu ser e de sua vida. ${ }^{36}$

A fé de Maria que se desabrochou no amor, se desabrochou também na esperança. No fiat de Maria está implicado o primeiro ato de esperança explicitamente cristão dirigido ao Verbo encarnado. Maria espera na promessa divina que se cumpre nela. Ela se abastece na presença do Deus que se encarna nela, com um novo impulso de desejo e um novo abandono. É a esperança silenciosa da mãe que se abastece naquele que está nela, um novo impulso de vida, uma sede ardente de ver o seu Deus. A esperança, com efeito, é o desejo eficaz de ver Deus, desejo que se apóia sobre o poder misericordioso de Deus. Maria, no seu fiat traduz esse desejo eficaz de buscar seu Deus, de possuí-lo, de ser possuída por Ele, se abandonando totalmente à sua misericórdia. A esperança de Maria é vivida dentro de um espírito de pobreza, e aqui se toca sua nota especificamente cristã, porque apoiada totalmente na misericórdia infinita de Deus. Maria apóia a sua esperança no seu filho ainda todo pequeno. Ela se apóia sobre a força de Deus que lhe é comunicada na fraqueza do "pequenino", daquele que se entrega a ela como um pequenino que tudo espera dela. Através da esperança no espírito de pobreza, a fé cristã se desabrocha em uma atitude de confiança. Maria confia na palavra de Deus que é promessa de vida para ela. Seu abandono se transforma em uma confiança inabalável naquele que lhe é dado, naquele que está para vir. ${ }^{37}$

A fé de Maria é também dom: Deus se deu a Maria porque ela se deu a Ele, e aí podemos perceber toda a fecundidade divina desse dom, pois Maria se dando, deu toda a humanidade a Deus, de modo que a Patrística considerava o fiat de Maria como o consentimento de toda a humanidade em núpcias divinas com o Verbo. Assim Maria possibilitou uma intimidade toda nova com Deus, seu Filho. O Pai comunica a Maria seu segredo de amor; o Filho também lhe comunica seu segredo pessoal de amor, e o Espírito Santo lhe pede uma docilidade perfeita no amor. Pelo fiat Maria penetrou no mistério da Trindade Santa, para viver desse mesmo mistério, de modo que a fé de Maria é vida contemplativa, que se realiza no silêncio. A fé de Maria é uma fé-silêncio. Existe um segredo, uma aliança nova entre ela e seu Deus, donde seu silêncio

\footnotetext{
${ }^{36}$ Ibidem, 102-103.

${ }^{37}$ Ibidem, p. 103-104.
} 
mesmo frente a José. Mas esse engajamento em uma vida contemplativa, a engaja ao mesmo tempo em uma vida de serviço a Deus e a seu povo, isso porque ela é a Serva do Senhor $(\operatorname{Lc} 1,38) .{ }^{38}$

\section{Maria, modelo de fé para a Igreja}

Nos primeiros séculos do cristianismo insistiu-se na identidade entre Maria e Igreja. A Igreja primitiva via a Igreja em Maria e Maria na Igreja. O seu grande amor pelo mistério da Igreja-Mãe, só se compreende a partir do grande amor que havia pela mãe terrestre do Salvador. ${ }^{39} \mathrm{Com}$ efeito, na Igreja primitiva, conhecia-se mais claramente e com mais entusiasmo o mistério segundo o qual a palavra de Deus, ao apresentar os traços de Maria Virgem-Mãe, no-la apresentava como a "figura e recapitulação" da Igreja-Mãe. Via-se também a vida inteira da Mãe de Deus, da sua concepção imaculada até a sua assunção, como uma só e única prefiguração do ser e do destino da Igreja e da nossa própria vida espiritual. E no seio desta Mãe, que nos deu o Deus Salvador, que começa a história da Igreja; e é na Igreja que se consuma, que se cumpre nossa própria destinação eterna; é nela que o mundo retorna a Deus e é salvo da decadência que a maldição do pecado original introduzira na criação.$^{40}$ Efrém, o Sírio, traduziu essa realidade de maneira profunda, dizendo: "A terra, esta mãe dos corpos humanos, foi maldita. Mas por amor do Corpo da Igreja, que jamais se corrompe, a terra deste Corpo foi abençoada desde o início: a terra da Igreja é, com efeito, o corpo de Maria, na qual ela foi semeada". ${ }^{41}$

Se o paralelo Maria/Eva não foi para santo Irineu simples artifício literário e nem improvisação gratuita, mas peça integrante de sua teologia da salvação; ${ }^{42}$ a mesma importância tinha para ele, o paralelo Maria/Igreja. Segundo ele, entre Maria e a Igreja existe uma relação de identidade, que toca de perto a identidade de Cristo com os seus membros, cuja realidade é muito mais importante do que aquilo que a palavra "mística" nos permite imaginar

\footnotetext{
${ }^{38}$ Ibidem, p. 105-111.

${ }^{39}$ Cf. Müller, A., Ecclesia - Maria. Die Einheit Marias und der Kirche, 63, (PG 7,1074).

${ }^{40}$ Ibidem , 12-13.

41"Já que os corpos pecaram, eles mesmos morrem e a terra, que é a sua mãe, foi amaldiçoada, da mesma forma, por causa da Igreja que também é um corpo, mas um corpo que não se corrompe, a terra foi abençoada logo de inicio; o corpo de Maria, eis a terra da Igreja, na qual ela foi gerada". Efrém Sírio, Ev. conc. exp., in Mösinger, G. Evangelii concordantis expositio facta a S. Ephraemo doctore Syro, 48-49, cit. por Müller, A. op. cit., 151.

${ }^{42}$ Cf. Laurentin, R., op. cit., 43.
} 
ou supor. ${ }^{43} \mathrm{O}$ Vaticano II retomou, na Lumen Gentium, a idéia patrística de Maria como tipo da Igreja, procurando mostrar assim a identidade profunda existente entre elas: "Em virtude da graça da divina maternidade e da missão pela qual está unida com seu Filho Redentor, e em virtude de suas singulares graças e funções, a Bem-aventurada Virgem está também intimamente relacionada com a Igreja. Já santo Ambrósio ensinava que a Mãe de Deus é o tipo da Igreja na ordem da fé, da caridade e da perfeita união do Cristo. No mistério da Igreja - pois também a Igreja é com razão chamada mãe e virgem- a Bem-aventurada Virgem Maria ocupa lugar eminente e singular como modelo de virgem e de mãe". ${ }^{44}$

Embora Maria transcenda a Igreja, ${ }^{45}$ as duas realidades se iluminam e se esclarecem mutuamente. No conceito de Maria como arquétipo da Igreja, temos a explicação de como Maria representa a essência mais íntima da Igreja. Como figura personificada da Igreja, a faz próxima dos homens, pois nela a Igreja una e múltipla aparece resumida como em germe, para se desdobrar na imensidade do espaço e do tempo, da mesma maneira que o título de um livro contém em germe todo o seu desenvolvimento, e é evidente que esse arquétipo deva conter uma espécie de programa para a atitude moral dos membros da Igreja. De outro lado, a Igreja ilumina a figura de Maria, pois se ela estiver separada desse conjunto ontológico dificilmente a personalidade de Maria, cuja vida nos é tão pouco conhecida em seus detalhes concretos, poderia ser proposta como modelo de vida cristã. ${ }^{46}$

O Concílio Vaticano II entendeu muito bem a relação e a unidade que existe entre Maria e a Igreja. Maria ao receber o Verbo de Deus no seu coração e no seu corpo, e trazendo a vida ao mundo, é reconhecida como a Mãe de Deus e do Redentor, e por ter dado à luz Cristo, cabeça da Igreja, ela é também mãe dos membros, que constituem a Igreja. Por isso ao mesmo tempo em que ela é membro supereminente e absolutamente singular da Igreja, é também seu modelo e protótipo acabado, na fé e na caridade. ${ }^{47}$

\footnotetext{
${ }^{43}$ Cf. Müller, A., op. cit., 75. P. Gächter caracteriza a nossa unidade com Cristo com a expressão: “übernatürlich-physische Verbindung”. Gächter P: „Unsere Einheit mit Christus nach dem hl. Irenäus“, in Zeitschr. f. kath. Theol 58 (1934), 503-532, apud por Müller, A., op. cit., 54.

${ }^{44}$ LG 63.

${ }^{45}$ As reflexões aqui desenvolvidas sobre a relação entre Maria e a Igreja, não nos devem conduzir à redução eclesiológica de Maria, pois ela é uma realidade complexa que transcende a Igreja.

${ }^{46} \mathrm{Cf}$. Semmelroth, O. Marie, archétype de l'Église, 31.

${ }^{47}$ Cf. Lumen Gentium, 53.
} 
Desde o Antigo Testamento a fé está no início da salvação do povo: "Abraão creu em Iahweh, e lhe foi tido em conta de justiça" (Gn 15, 6). O povo crê e isso se torna o início de sua salvação: "E o povo creu. E tendo se alegrado porque Iahweh visitara os filhos de Israel e vira a sua aflição, eles se ajoelharam e se inclinaram" (Ex 4, 31). E na origem do Povo de Deus, do novo Israel, temos o ato de fé de Maria, que creu nas palavras do anjo, que era a palavra de Deus, e a salvação fez entrada no mundo. São Bernardo de Claraval descreveu o momento da Anunciação como um momento dramático, momento no qual estávamos como que pendurados nos lábios de Maria:48 "Ouviste, ó Virgem, que vais conceber e dar à luz um filho, não por obra de homem - tu ouviste - mas do Espirito Santo. O anjo espera tua resposta: já é tempo de voltar para Deus que o enviou: já é tempo de voltar para Deus que o enviou. Também nós, Senhora, miseravelmente esmagados por uma sentença de condenação, esperamos tua palavra de misericórdia. Eis que te é oferecido o preço de nossa salvação; se consentes, seremos livres. Todos fomos criados pelo Verbo eterno. Mas caímos na morte; com uma breve resposta tua seremos livres. Todos fomos criados pelo Verbo eterno. Mas caímos na morte; com uma breve resposta tua seremos recriados e novamente chamados à vida (...). Se disseres sim, seremos salvos; se disseres não, estamos perdidos para sempre"49.

Para a nossa felicidade, a resposta de Maria foi o sim, of fiat $(\operatorname{Lc} 1,38)$. O fiat o ato de fé de Maria foi suscitado pelo Espírito Santo, pois graça e fé são os dois pilares da salvação; "são para o homem os dois pés para andar, ou duas asas para voar. Não são, porém, duas coisas paralelas, como se de Deus viesse a graça e de nós a fé, dependendo assim a salvação, em partes iguais, de Deus e de nós, da graça e da liberdade. Seria um engano se alguém pensasse: a graça depende de Deus, mas a fé depende de mim; juntos, eu e Deus fazemos a salvação! Novamente estaríamos fazendo de Deus um devedor, alguém que de algum modo depende de nós, e que deve partilhar conosco o mérito e a glória. São Paulo tira qualquer dúvida quando diz: "é pela graça que fostes salvos, mediante a fé e isto (quer dizer, o fato de acreditarmos, ou, mais globalmente, o fato de sermos salvos pela graça através da fé, o que é a mesma coisa) não é a vós que se deve; é dom de Deus para ninguém se poder gloriar (Ef 2, 8s).$^{50} \mathrm{E}$ Maria foi plenamente consciente desse dom de Deus, da gratuidade da graça e da fé, pois foi isso que a fez dizer: "Eu sou a serva do Senhor; faça-se em mim segundo a tua palavra” (Lc 1,38).

\footnotetext{
${ }^{48}$ Cf. Lorscheider, Aloísio. A fé da Virgem Maria, p. 10.

${ }^{49}$ São Bernardo Claraval. Hom 4, 8-9, apud Lorscheider, Aloísio, op. cit., p. 10.

${ }^{50}$ Cantalamessa, R. Maria, um espelho para a Igreja, p. 42.
} 


\section{Maria e a Nova Evangelização}

O tema central dos Atos dos Apóstolos é o testemunho do Senhor Ressuscitado, que embora se refira principalmente aos doze apóstolos, mas se estende a todos os membros da comunidade. Porém a figura de uma Maria evangelizadora talvez seja estranha ao imaginário coletivo dos cristãos, embora conforme os dados neotestamentários façam dela, evidentemente depois de Cristo consagrado e enviado ao mundo (Jo 10,36) e em comunhão com os apóstolos, a primeira e a mais alta expressão da Igreja evangelizadora.

A vocação de Maria não foi ordenada somente à maternidade messiânica (Lc 1,30-33), pois já na visitação ela atua como a "protomissionária" e antecipa a Igreja na dinâmica "consagração no Espírito-missão apostólica". Coberta e consagrada pelo Espírito ( $\operatorname{Lc} 1,35)$, Maria se põe a caminho até a Judéia levando em seu seio o Salvador e desta forma antecipou a viagem de Jesus até Jerusalém (Lc 9,51); viagem missionária e salvífica enquanto a saudação de Maria provoca a efusão carismática do Espírito sobre Isabel que discerne na jovem prima a Mãe do Senhor, e também sobre João Batista que salta de alegria na presença do Messias dentro de Maria de cujo coração transborda o cântico pneumático do Magnificat.

O Espírito desce sobre Maria em Pentecostes e também desce sobre os apóstolos e outros membros da comunidade, os consagra e os torna testemunhas de Cristo ressuscitado. Também a Mãe de Jesus é parte desse grupo de pessoas "que ficaram repletos do Espírito Santo e começaram a falar em outras línguas, conforme o Espírito lhes concedia se exprimissem" (At 2,4). ${ }^{51}$ Maria esteve presente assim no primeiro anúncio do evangelho. O missionário é o apóstolo do kerigma ou o primeiro anúncio. Maria, virgem e mãe, forma parte do anúncio do evangelho. Se anuncia a Cristo verdadeiro homem, filho de Maria, e verdadeiro Deus, pois Maria Virgem concebeu por obra do Espírito Santo; Cristo é o Redentor e Salvador, e Maria, figura da Igreja, está associada à obra redentora. Assim Maria faz parte do primeiro anúncio missionário, como a mulher da qual, por obra do Espírito Santo, nasce Cristo, o Filho de Deus Feito homem, nosso Salvador. ${ }^{52}$

A razão de ser de Maria e da Igreja é a de receber a Cristo para anunciá-lo ao mundo. A Igreja olha para Maria como ponto de referência para os povos

\footnotetext{
${ }^{51}$ Ibidem, 55.

${ }^{52}$ Cfr. BIFET, J. E., Misionología. Evangelizar en un mundo global. Madrid: BAC, 2008.
} 
e para a humanidade inteira (DAp, 268). ${ }^{53}$ Maria precede a Igreja como o grande sinal (Ap 12,1), como "a estrela da evangelização. ${ }^{54}$ Este título mariano indica que Maria é "tipo", figura e personificação da Igreja, que é virgem, mãe e missionária. A Igreja se sente identificada com Maria na missão universal, pois ela foi a primeira evangelizada e se tornou também a primeira discípula, a primeira missionária na visitação à sua prima Isabel, anunciando a Boa Nova ao levar o Cristo no seu ventre para proclamá-lo como o Messias, Salvador e Redentor. Assim Maria personifica para nós a figura do discípulo missionário, como foi preconizada pela Conferência de Aparecida.

Maria foi a primeira evangelizada, e é a evangelizadora por excelência. $\mathrm{Na}$ história das missões, em muitos casos ela precedeu o anúncio do Cristo. Como em Guadalupe, ela leva a querer "ver Jesus", como nos mostra o texto do Doc. 72 da $\mathrm{CNBB}^{55}$ : Queremos ver Jesus - caminho, verdade e vida, 4.1: "Queremos ver Jesus" (Jo 12, 21) é o que dizem alguns pagãos que tinham subido a Jerusalém para prestar culto a Deus, na festa da Páscoa. Filipe ouve esse pedido, chama André, e os dois juntos transmitem esse desejo a Jesus. Hoje, mesmo sem saber expressar desse modo o que buscam, são muitos os que querem ver, conhecer e encontrar Jesus. Na verdade, ele é a resposta aos anseios mais profundos do ser humano, pois "ilumina todo ser humano que vem a este mundo" (Jo 1, 9). Hoje, cada batizado precisa ser esse tipo de instrumento, para que o mundo desorientado encontre o rumo da salvação, da vida plena que Deus deseja para todos e que é oferecida em Jesus".

Maria é a Mãe da Igreja evangelizadora e sem Ela não se compreende o espírito da Nova Evangelização, uma vez que Jesus ao dizer do alto da cruz: "Mulher, eis teu filho!" e "Eis a tua mãe!" (Jo 19,26-27) quis manifestar o mistério de uma missão salvífica especial para ela, ou seja, Jesus deixava-nos a sua Mãe como nossa Mãe, e só depois disso pôde dizer que "tudo estava consumado" (Jo 19,28). ${ }^{56}$ Jesus quis mostrar que não se caminha sem uma mãe, de maneira que deve existir uma ligação íntima entre Maria e a Igreja e cada fiel. ${ }^{57}$ Assim Maria é a Estrela da Nova Evangelização. Podemos pedir a ela que interceda, que essa nova etapa da evangelização, a Nova Evangeli-

\footnotetext{
${ }^{53}$ Cfr. Redemptoris Mater, 6.

${ }^{54}$ Cfr. Evangelii Nuntiandi, 82.

${ }^{55}$ Documentos da CNBB no 72. Projeto Nacional de Evangelização (2004-2007) - Queremos ver Jesus - Caminho, Verdade e Vida. 5ㅉe ed. São Paulo: Paulinas, 2005.

${ }^{56}$ Cf. PAPA FRANCISCO. Evangelii gaudium, 284-285. Brasília: CNBB, 2013.

${ }^{57}$ Ibidem, 285.
} 
zação, que esse compromisso seja assumido por toda a comunidade eclesial, que possamos anunciar a todos a mensagem da salvação e para que os novos discípulos se tornem operosos evangelizadores. ${ }^{58} \mathrm{~A}$ atividade evangelizadora da Igreja deve ser conforme o estilo mariano, em que se acredita na força revolucionária da ternura e do afeto. Olhando para ela "vemos que a humildade e a ternura não são virtudes dos fracos, mas dos fortes, que não precisam maltratar os outros para se sentirem fortes" ${ }^{\prime 9}$. Como mulher orante e trabalhadora, pronta para ir apressadamente em socorro dos que precisam (Lc 1,39), e "esta dinâmica de justiça e ternura, de contemplação e de caminho para os outros faz dela um modelo eclesial para a evangelização"

Enfim, conforme a Lumen Gentium, sendo Maria, "membro supereminente e absolutamente singular da Igreja"61, a sua presença é inegável, presença como modelo de fé, para evangelizar e para ser evangelizado; ela está presente na Nova Evangelização estando presente na comunidade eclesial, em atitude orante e contemplativa, como no início da Igreja, no dia de Pentecostes: "Todos estes, unânimes, perseveravam na oração com algumas mulheres, entre as quais Maria, a mãe de Jesus" (At 1,14), mas também como peregrina $^{62}$ e companheira, presente nas comunidades eclesiais e nos movimentos sociais, nos mostrando através do seu Magnificat (Lc 1,46-55), de que Deus é o protagonista da história e que nós somos convidados e convocados para participar nessa grande epopeia da salvação.

\section{Conclusão}

Partimos de um quadro desanimador: igrejas vazias, abandono da fé, indiferença religiosa. Porém a proposta de uma Nova Evangelização é cheia de esperanças, pois trata-se de anunciar, de propor um encontro não somente com uma doutrina, mas um encontro real, pessoal e existencial com Jesus Cristo, o Mestre, o Libertador, o Redentor. E aprendemos com Maria a termos um olhar de fé para o mistério da pessoa de seu Filho e a nos tornarmos com ela, testemunhas de um novo mundo e assim levar adiante o projeto de uma Nova Evangelização. Vimos que Maria evangelizadora depois de Cristo consagrado

\footnotetext{
${ }^{58}$ Ibidem, 287.

${ }^{59}$ PAPA FRANCISCO. Evangelii gaudium, 288.

${ }^{60}$ Ibidem, 288.

${ }^{61}$ Lumen Gentium, 53.

${ }^{62}$ Cf. a encíclica de João Paulo II: Redemptoris Mater.
} 
e enviado ao mundo (Jo 10,36) e em comunhão com os apóstolos, é a primeira e a mais alta expressão da Igreja evangelizadora. Na história das missões, em muitos casos ela precedeu o anúncio do Cristo. Como em Guadalupe, ela leva a querer "ver Jesus". Maria está presente na Nova Evangelização como modelo e protótipo de fé, e como membro eminente da Igreja, intercedendo por nós como fez nas bodas de Caná (Jo 2), suscitando a fé dos discípulos de Jesus e agora suscitando a nossa fé em Jesus, e ela permanece na comunidade eclesial orante e atuante, nos ensinando a escutar a Palavra de Deus e nos animando para o compromisso missionário e generosidade na doação.

\section{Referências Bibliográficas}

ARANDA, A. (ed.). María, camino de retorno. Nueva evangelización y piedad mariana. Navarra, EUNSA, 2012.

ARANDA, A. Una nueva evangelización. Como acometerla? Madri: Ediciones Palabra, 2012.

BENTO XVI. Carta Apostólica em forma de "Motu próprio": Ubicumque et semper com a qual se institui o Pontifício Conselho para a promoção da Nova Evangelização, dado em Castel Gandolfo, no dia 21 de Setembro de 2010, Festa de São Mateus, Apóstolo e Evangelista, no sexto ano de Pontificado do Papa Bento XVI. Tipografia Vaticana.

BERTOLOTE, J. M. (org.). Glossário de termos de psiquiatria e saúde mental da CID-10 e seus derivados. Porto Alegre: Artes Médicas, 1997.

BIFET, J. E. Misionología. Evangelizar en un mundo global. Madrid: BAC, 2008.

CANTAlAmESSA, R. Maria, um espelho para a Igreja. Aparecida: Ed. Santuário, 1992.

Documento de Aparecida. Texto conclusivo da V Conferência Geral do Episcopado Latino-Americano e do Caribe. 13-31 de maio de 2007. São Paulo: Edições CNBB/Paulus/Paulinas, 2007.

Documentos da CNBB no 72. Projeto Nacional de Evangelização (2004-2007) - Queremos ver Jesus - Caminho, Verdade e Vida. 5a ed. São Paulo: Paulinas, 2005. 
FISICHELLA, R. La nouvelle évangélisation. Paris: Salvator, 2012.

FRANCISCO, Papa. Encíclica Lumen fidei. Sobre a fé. São Paulo: Paulus/ Loyola, 2013.

FRANCISCO, Papa. Exortação Apostólica Evangelii gaudium. A alegria do Evangelho. Brasília: CNBB, 2013.

HOlAndA FERREIRA, A. B. de. Mini Aurélio. O Dicionário da Língua

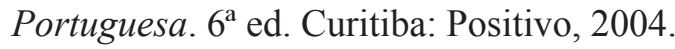

JOÃO PAULO II. Exortação Apostólica Pós Sinodal: Christifideles laici. Libreria Editrice Vaticana, 1998.

JOÃO PAULO II. Carta encíclica: "Redemptoris Mater". In: Encíclicas de João Paulo II. Col. Documentos da Igreja. São Paulo: Paulus, 1997.

Laurentin, R., Court traité sur la Vierge Marie. Refondu à la suite du Concile. $5^{\text {a }}$ ed. Paris: Lethielleux, 1967.

LOIOLA, Santo Inácio. Exercícios Espirituais. 1ª ed. Porto Alegre, 1966.

Lorscheider, A., A fé da Virgem Maria. Col. Cadernos Marianos 2. Aparecida: Ed. Santuário, s. d.

LUMEN GENTIUM. Constituição Dogmática sobre a Igreja. In: Documentos do Concílio Vaticano II (1962-1965). São Paulo: Paulus, 2001.

MACCAGNAN, V. Guadalupe: Evangelio y Cultura. Mexico: Ideal Editores, 2000.

MARCOZZI, V. Verbete: "Discernimento dos espíritos". In: Borrielo, L. et alii (Dir.). Dicionário de Mística. São Paulo: Loyola/Paulus, 2003, p. 334.

Müller, A., Ecclesia - Maria. Die Einheit Marias und der Kirche. $2^{\mathrm{a}}$ ed. Freiburg in der Schweiz: Universitäts Verlag, 1955.

MOSCONI, L. A vida é missão. Para uma missiologia mística popular. $1^{\mathrm{a}} \mathrm{ed}$. Belém: Marques Editora, 2012.

PAULO VI. Exortação Apostólica: Evangelii Nuntiandi. In: Documentos de Paulo VI. Col. Documentos da Igreja. São Paulo: Paulus, 1997.

Philippe, M-D., Mystère de Marie. Croissance de la vie chrétienne. Paris: Fayard, 1999. 
SCHERER, Cardeal Odilo Pedro. Por ocasião do Domingo das Missões. Disponível em: http://www.cnbb.org.br/articulistas/cardeal-odilo-pedroscherer/13031-missao-nova-evangelizacao Acesso em 21/01/2014.

SÍNODO DOS BISPOS. A nova evangelização para a transmissão da fé cristã. Instrumentum laboris. Brasília: CNBB, 2012.

VV.AA. Mapa de la nueva evangelización. Madri: dBolsillo, 2012.

\section{Pedro K. Iwashita CSSp}

Doutor em Teologia pela Universidade de Fribourg, Suiça Professor titular da Faculdade de Teologia da PUC/SP, do curso de Graduação e do Programa de Pós Graduação em Teologia Diretor Adjunto da Faculdade de Teologia da PUC/SP

São Paulo/SP - Brasil E-mail: iwashita@uninet.com.br

Recebido em: 03/02/14 Aprovado em: 17/02/14 